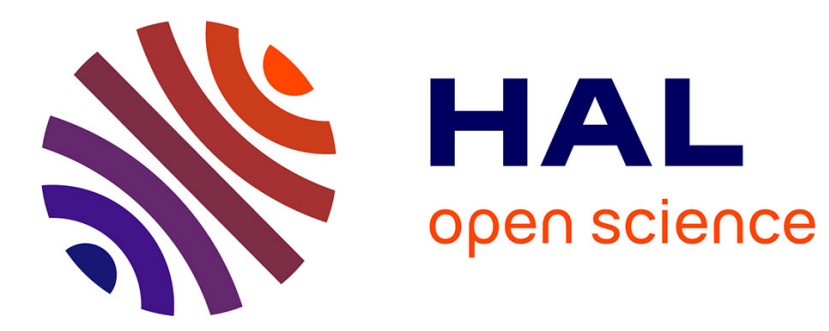

\title{
Transition Metal-Mediated Dinitrogen Functionalisation with Boron
}

Antoine Simonneau

\section{To cite this version:}

Antoine Simonneau. Transition Metal-Mediated Dinitrogen Functionalisation with Boron. New Journal of Chemistry, 2021, 45 (21), pp.9294-9301. 10.1039/D1NJ01290H . hal-03245930

\section{HAL Id: hal-03245930 \\ https://hal.science/hal-03245930}

Submitted on 2 Jun 2021

HAL is a multi-disciplinary open access archive for the deposit and dissemination of scientific research documents, whether they are published or not. The documents may come from teaching and research institutions in France or abroad, or from public or private research centers.
L'archive ouverte pluridisciplinaire HAL, est destinée au dépôt et à la diffusion de documents scientifiques de niveau recherche, publiés ou non, émanant des établissements d'enseignement et de recherche français ou étrangers, des laboratoires publics ou privés. 


\title{
Transition Metal-Mediated Dinitrogen Functionalisation with Boron
}

\author{
Antoine Simonneau*
}

The quest for efficient dinitrogen transformations has continuously attracted interest from the chemical community. Since the advent of dinitrogen coordination chemistry, $\mathrm{N}_{2}$ complexes have proven valuable platforms for the conversion of dinitrogen into valuable compounds such as ammonia or silylamines. Although less developed, probably as a consequence of challenging implementation into catalysis, functionalization of $\mathrm{N}_{2}$ with other elements than $\mathrm{H}$ or Si does hold great promise in view of the ubiquity of nitrogen-containing compounds and materials in chemistry. The present article focuses on the currently available methods to functionalise dinitrogen activated by transition metal centres with boron reagents resulting in $\mathrm{N}-\mathrm{B}$ bond formation.

\section{Introduction}

Dinitrogen, $\mathrm{N}_{2}$, is commonly considered as an inert molecule. As the primary constituent of our atmosphere, it represents an inexhaustible and unique, widely available source of the element $\mathrm{N}$, which is crucial for all living organisms on Earth. Therefore, its transformation into more reactive sources of nitrogen is of vital importance for life to be sustained. In Nature, some bacteriae express an enzyme, the nitrogenase, which gives them the ability to reduce $\mathrm{N}_{2}$ into ammonia $\left(\mathrm{NH}_{3}\right)$ through a process called nitrogen fixation. ${ }^{1}$ The whole biosphere takes advantage of this fixed and reactive nitrogen as it can be easily metabolised. The food crisis that plagued Europe at the advent of the $20^{\text {th }}$ century, due to demographic explosion and shortage of nitrate ore - the nitrogen fertilizer employed at the timehas pushed chemists to find a reliable method to artificially perform nitrogen fixation and provide enough fixed nitrogen to fertilize soils and increase crop yields to sustain a growing population. The Haber-Bosch process was developed for that purpose, and still remains one of the most important industrial processes, more than a century after its discovery. It allows the reduction of $\mathrm{N}_{2}$ into $\mathrm{NH}_{3}$ by hydrogenolysis over an heterogeneous iron catalyst and has supplied mankind with sufficient amounts of nitrogen fertilizers to sustain its intensive agriculture. ${ }^{2}$ Although efficient, the sustainability issues posed by the Haber-Bosch process (high energy consumption and large $\mathrm{CO}_{2}$ emissions) has motivated a quest for greener nitrogen fixation methods. Inspired by the nitrogenases, that features an active site that incorporate an iron-sulfur cluster to which $\mathrm{N}_{2}$ binds before it is reduced, coordination and organometallic chemists have devised ways to activate and transform dinitrogen using molecular complexes that bind $\mathrm{N}_{2},{ }^{3}$ eventually achieving catalytic, homogeneous $\mathrm{N}_{2}$-to- $\mathrm{NH}_{3}$ reaction. ${ }^{4}$ But it would be forgetful not to recognise another important and exclusive aspect of dinitrogen coordination complexes, which is their ability to build bonds between $\mathrm{N}_{2}$ 's nitrogen atoms and elements other than $H$. Thus, amines, silylamines and borylamines have been prepared from dinitrogen complexes by reacting $\mathrm{N}_{2}$ complexes with carbon, silicon and boron reagents, respectively. ${ }^{3 a, b}$ While still in its infancy, the synthesis of borylamines from $\mathrm{N}_{2}$ is an attractive goal since such compounds have been employed as molecular precursors en route to ordered boron nitride-based materials. ${ }^{5}$ The present article gives an overview of the available methods to create covalent $\mathrm{B}-\mathrm{N}$ bonds between a dinitrogen (or a $\mathrm{N}_{2}$-derived nitrido) ligand and a boron-based reagent, the first elementary step to look at when targeting the preparation of $\mathrm{N}_{2}$-sourced borylamines.

\section{Group 4 Metals}

\section{$\mathrm{N}_{2}$ Borylation Relying on Titanium Hydride Complexes}

The group of Hou has reported dinitrogen cleavage and hydrogenation using a trinuclear, mixed-valence titanium polyhydride complex $\mathbf{1}$ leading to a tris-imido/nitrido complex $\mathbf{2}$ (Scheme 1, top). ${ }^{6}$ The latter was shown to react with 3 equiv. of pinacolborane (HBpin) to give the tris-borylimido/nitrido species 3 through dehydrogenative coupling between the hydroborane and the imido moieties. ${ }^{7}$ The same group has recently documented the reactivity of a side-on, end-on dinitrogen dititanium hydride complex 4 in which the two metal centres are stabilised by and acridine-based PNP pincer ligand (acripNP, see Scheme 1, bottom). ${ }^{8}$ Compared to a similar system from the same group, ${ }^{9}$ the rigidity imparted by the acriPNP ligand was key to observe various reactions with main group organometallics. Notably, treatment of 4 with $B\left(C_{6} F_{5}\right)_{3}$ led to the rapid formation of the Lewis acid-base adduct $\mathbf{5}$. Lewis acid coordination was proposed to trigger $\mathrm{N}-\mathrm{N}$ bond cleavage over days in $\mathrm{Et}_{2} \mathrm{O}$ at room temperature, followed by $\mathrm{B}-\mathrm{C}$ bond cleavage and covalent $\mathrm{B}-\mathrm{N}$ bond formation to afford a borylimido/ $\mu_{2}$-nitrido Tiv compound 6 . $\mathrm{N}$-borylation ensuing $\mathrm{N}-$ $\mathrm{N}$ bond scission was also observed in the reaction of $\mathbf{4}$ with two equivalents of pinacolborane (HBpin). The authors proposed that, after the loss of $\mathrm{H}_{2}$, the $\mathrm{N}-\mathrm{N}$ bond is cleaved to lead to an intermediate dinuclear Ti(IV) nitride 7 . Double 1,2 addition of B$\mathrm{H}$ bonds across the $\mathrm{Ti}-\mathrm{N}$ double bonds ${ }^{10}$ may then afford the bis(borylimido)-bridged dititanium dihydride species 8 (not observed), which subsequently loses $\mathrm{H}_{2}$ to afford the dititanium complex 9. 

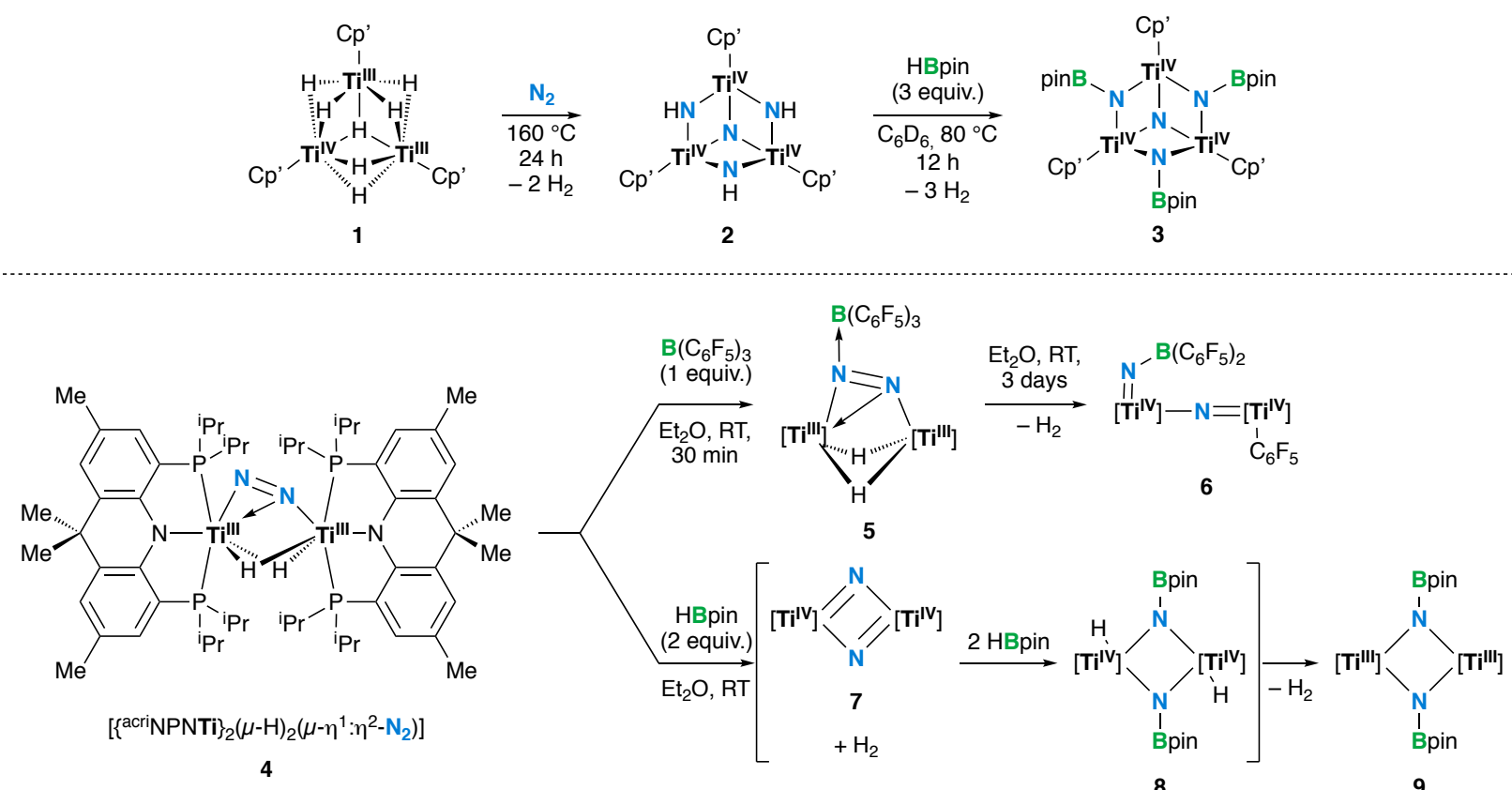

Scheme $1 \mathrm{~N}_{2}$ cleavage and hydrogenation promoted by titanium hydrides and their subsequent reactivity with boranes results in B-N bond formation.

\section{Metallocenes of Zirconium and Hafnium}

The group of Chirik has successfully demonstrated that dinuclear, side-on bound dinitrogen metallocene complexes based on Zirconium and Hafnium could engage in a wide array of nitrogen-element bond-forming events. ${ }^{11}$ Zirconium and hafnium bimetallic $\mathrm{N}_{2}$ complexes 10 stabilised with the 1,2,4trimethylcyclopentadienyl ligand reacted with pinacolborane to afford $\mathrm{N}$-borylated compound $\mathbf{1 1}$, obtained as a mixture of $C_{1}$ and $C_{\mathrm{s}}$ isomers in the case of hafnium (Scheme 2). ${ }^{11 p}$ Other hydroboranes have not been examined. Further reactivity was explored and, in particular, the authors have shown that when exposed to $\mathrm{CO}$, the $\mathrm{N}-\mathrm{N}$ bond in $\mathbf{1 1}$ was cleaved concomitantly with $\mathrm{C}-\mathrm{N}$ bond formation $(\mathbf{1 1} \longrightarrow \mathbf{1 2})$.

\section{Group 5 Metals}

In the 2000s, the group of Fryzuk has extensively studied the reactivity of the side-on, end-on dinitrogen ditantalum hydride complex 13 supported by the NPN ligand (NPN = $\left.\left(\mathrm{PhNSiMe}{ }_{2} \mathrm{CH}_{2}\right)_{2} \mathrm{PPh}\right),{ }^{12}$ which core structure resembles those of the dititanium complexes later studied by the group of Hou (vide supra). ${ }^{8,9}$ Notably, secondary or primary hydroboranes such as 9-BBN, $\mathrm{HBCy}_{2}$ or thexylborane reacted with 13 by 1,2$\mathrm{B}-\mathrm{H}$ bond addition over one $\mathrm{Ta}-\mathrm{N}$ bond to afford boryldiazenido complexes 14 (Scheme 3). ${ }^{13}$ By contrast with the report from Hou's team, the Ta complex 13 readily reacted with hydroboranes, while the structurally related dititanium compound 4 (Scheme 1) was proposed to eliminate $\mathrm{H}_{2}$ and undergo $\mathrm{N}-\mathrm{N}$ bond cleavage before $\mathrm{N}$-borylation with HBpin. However, the Fryzuk group observed that $\mathrm{N}$-borylation in $\mathbf{1 4}$ was followed by $\mathrm{H}_{2}$ loss, leading presumably to a transient TaTa bonded intermediate (not shown) in which $\mathrm{N}-\mathrm{N}$ bond scission occurred. Reaction of the thus-formed bridging nitride in intermediate $\mathbf{1 5}$ with the NPN ligand backbone then afforded complex 16 showing a square silylimido-nitrido $\mathrm{Ta}_{2} \mathrm{~N}_{2}$ motif. Interestingly, the $\mathrm{B}-\mathrm{H}$ bond re-formed during that process, the hydride bridging the $B$ and Ta centres, and the $B$ atom had a weaker interaction with the $\mathrm{N}$ atom than in $\mathbf{1 4}\left(\mathrm{d}_{\mathrm{BN}}=1.517\right.$ (8) $\AA$ in 16 vs. $1.40(2) \AA$ in 14). In the case of the 9-BBN and $\mathrm{BCy}_{2}$ derivatives, further reactivity was observed, as the terminal phenylimido in 16, formed after cleavage of the ligand's N-Si bond, reacted with the proximal coordinated hydroborane to provide a borylimido moiety concomitantly with the release of benzene $(16 \longrightarrow 17 a, b)$.

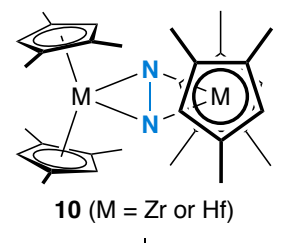

$\downarrow$ HBpin (1 equiv.)

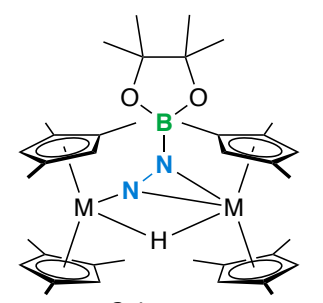

$C_{s}$ isomer

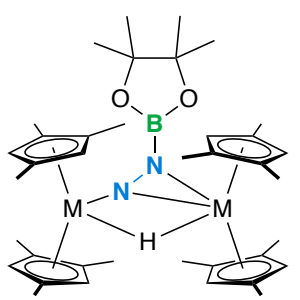

$C_{1}$ isomer

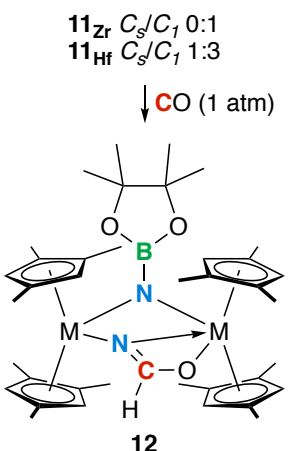

12

Scheme 2 Borylation of the dinitrogen ligand with HBpin in dinuclear $\mathrm{Zr}$ and $\mathrm{Hf}$ metallocene $\mathrm{N}_{2}$ complexes. 
The authors could not observe a similar rearrangement for the thexyl derivative. The reaction of $\mathbf{1 3}$ with Piers' borane $\mathrm{HB}\left(\mathrm{C}_{6} \mathrm{~F}_{5}\right)_{2}$ did not lead to $1,2-\mathrm{B}-\mathrm{H}$ bond addition, instead a stable Lewis acid-base adduct $\mathbf{1 8}$ was observed. ${ }^{14}$

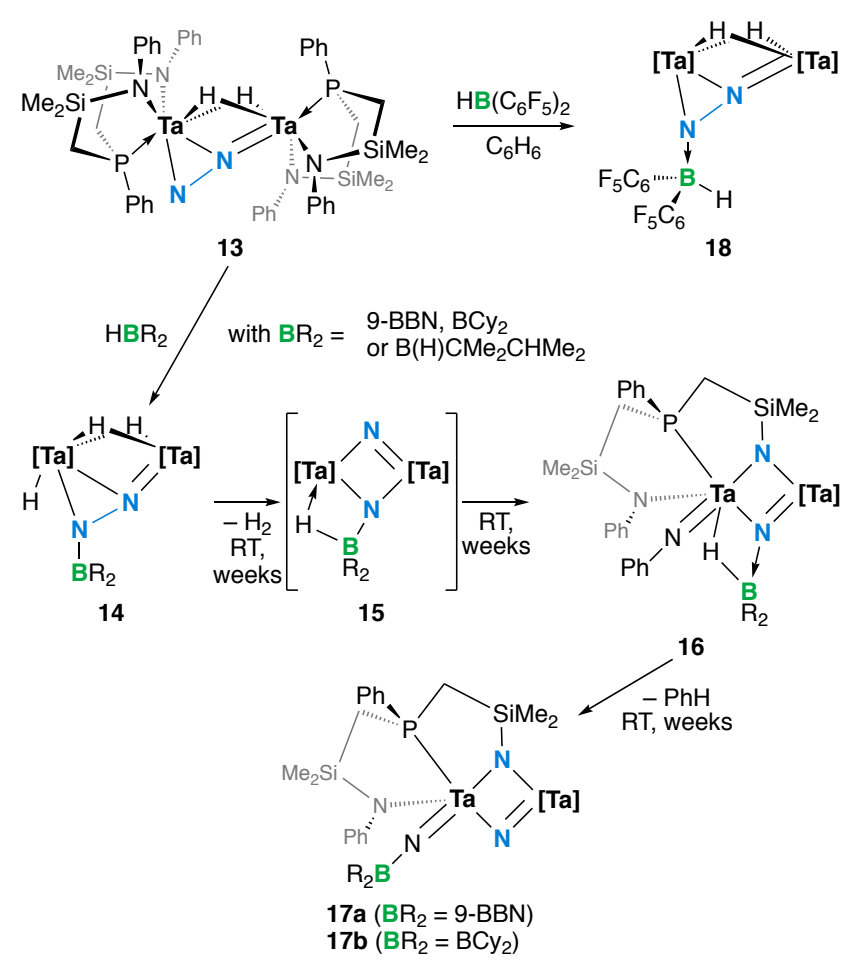

Scheme 3 Reactivity of the dinuclear side-on, end-on dinitrogen Ta complex with hydroboranes.

\section{Group 6 Metals}

\section{Early Works}

The Hidai group is one of the research team to have pioneered the chemistry of dinitrogen complexes, especially with lowvalent group 6 metal-phosphine compounds. It was indeed the first to report the reaction of a dinitrogen complex with boron reagents leading to $\mathrm{B}-\mathrm{N}$ bond formation. In this seminal publication, the anionic tungsten complex 19 reacted with thexylborane to produce the neutral boryldiazenido compound 20 with the tris-hydridoborate salt $\left[\mathrm{NBu}_{4}\right]\left[\mathrm{H}_{3} \mathrm{BCMe} \mathrm{CHMe}_{2}\right]$ as by-product (Scheme 4). ${ }^{15}$ Dialkylboranes such as 9borabicyclo[3.3.1]nonane (9-BBN) and dicyclohexylborane $\left(\mathrm{HBCy}_{2}\right)$ reacted more sluggishly (not shown). The authors emphasised the fact that related, neutral dinitrogen complexes remained unreactive towards thexylborane as a result of lower $\mathrm{N}_{2}$ activation. However, the former were reactive towards more electrophilic boron-pseudohalide reagents, such as 9borabicyclo[3.3.1] nonyl triflate (9-OTf-BBN). In its presence, $\mathrm{N}_{2}$ complex $\mathbf{2 1}$ was converted to the boryldiazenido triflate compound 22. Intriguingly, in the solid state structure of 22, the $\mathrm{W}-\mathrm{N}-\mathrm{N}-\mathrm{B}$ array is linear, likely for steric reasons. This contrasts with commonly encountered bent M-N-N-B motifs found in other structures of boryldiazenido complexes.

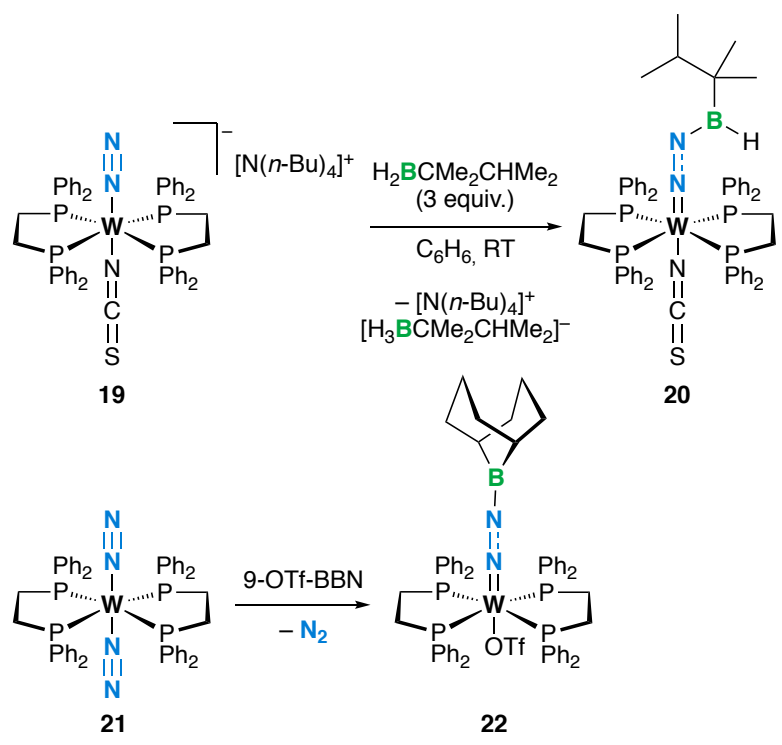

Scheme 4 Borylation of zero-valent end-on tungsten- $\mathrm{N}_{2}$ complexes

\section{Frustrated Lewis Pair (FLP)-inspired Borylation and 1,3-B-H bond addition}

Our group has recently studied the reactivity of Lewis adducts of $\mathrm{B}\left(\mathrm{C}_{6} \mathrm{~F}_{5}\right)_{3}$ with group 6 , zero-valent bis-dinitrogen complexes supported with phosphines, taking inspiration from the frustrated Lewis pair (FLP) chemistry. ${ }^{16}$ Especially, we have shown that adducts $\mathbf{2 3}$ efficiently performed the heterolytic, FLP-type cleavage of Piers' borane' $\mathrm{s}^{17} \mathrm{~B}-\mathrm{H}$ bond ${ }^{18}$ to afford ionic complexes $\mathbf{2 4}$ in which the $\mathrm{N}_{2}$ ligand was borylated (Scheme 5). ${ }^{19}$

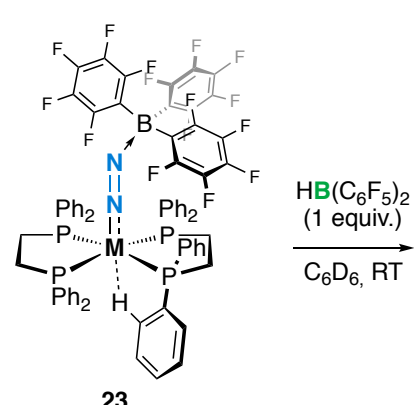

23

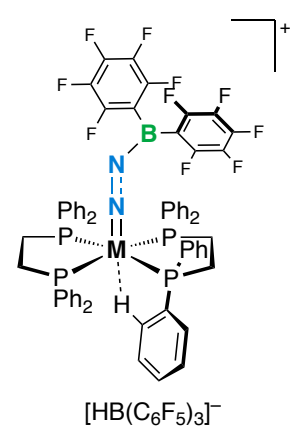

24
Scheme 5 FLP-type B-H bond activation by $\mathrm{N}_{2}$ complex- $\mathrm{B}\left(\mathrm{C}_{6} \mathrm{~F}_{5}\right)_{3}$ combinations ( $\mathrm{M}$ $=$ Mo or $\mathrm{W}$ ).

Further investigations on Piers' borane reactivity with $\mathrm{N}_{2}$ tungsten complex $\mathbf{2 1}$ have shown that it alone is an effective $\mathrm{N}_{2}$ borylation agent, leading to boryldiazenido complex 25 (Scheme 6). ${ }^{20}$ Similar reactivity was observed with the monophosphine $\mathrm{N}_{2}$ complex $\left[\mathrm{W}\left(\mathrm{N}_{2}\right)_{2}\left(\mathrm{PMe}_{2} \mathrm{Ph}\right)_{4}\right]$ (not shown). Solid-state structures allowed us to differentiate these reactions from the one described in Scheme 5 as Piers' borane demonstrated its ability to easily dissociate a phosphine, a phenomenon that was not observed when the more sterically hindered $\mathrm{B}\left(\mathrm{C}_{6} \mathrm{~F}_{5}\right)_{3}$ was employed. Heterolytic $\mathrm{B}-\mathrm{H}$ bond cleavage, similarly to the reaction affording $\mathbf{2 4}$, generates a bis(hydrido) borate anion that was found, according to crystallographic data, to interact with the metallic centre, while in 24 the $\left[\mathrm{HB}\left(\mathrm{C}_{6} \mathrm{~F}_{5}\right)_{3}\right]^{-}$anion was clearly separated from the cationic part. Such interaction was possible due to the liberation 
of a coordination site after phosphine dissociation as well as the bidenticity and suitable steric demand of $\left[\mathrm{H}_{2} \mathrm{~B}\left(\mathrm{C}_{6} \mathrm{~F}_{5}\right)_{2}\right]^{-}$. It is likely that the borylation of $\mathbf{1 9}$ reported by Hidai and colleagues, producing a tris(hydrido)borate anion (Scheme 4), shares similar mechanistic features (B-H bond cleavage) to our work. $A$ remarkable ligand effect was found when we examined the reactivity of the depe-supported $\mathrm{W}$ complex 26 (depe = 1,2bis(diethlyphosphino)ethane). Indeed, thanks to the strong $\sigma$ donor ability of the ligand coupled to the chelating effect, Piers' borane was not able to dissociate a phosphorus atoms like in $\mathbf{2 5}$, leading to a different interaction of the $\left[\mathrm{H}_{2} \mathrm{~B}\left(\mathrm{C}_{6} \mathrm{~F}_{5}\right)_{2}\right]^{-}$anion with tungsten in complex 27, now located in trans relationship to the boryldiazenido ligand (Scheme 6). Upon heating at $40{ }^{\circ} \mathrm{C}$ or addition of another equivalent of $\mathrm{HB}\left(\mathrm{C}_{6} \mathrm{~F}_{5}\right)_{2}, \mathrm{~W}-\mathrm{H}$ bond formation occurred, leading to the formal 1,3-B-H addition compound 28. Repeating the experiment with a slight excess of Piers' borane at $40{ }^{\circ} \mathrm{C}$ allowed us to obtain the boryldiazenidohydrido compound 29.

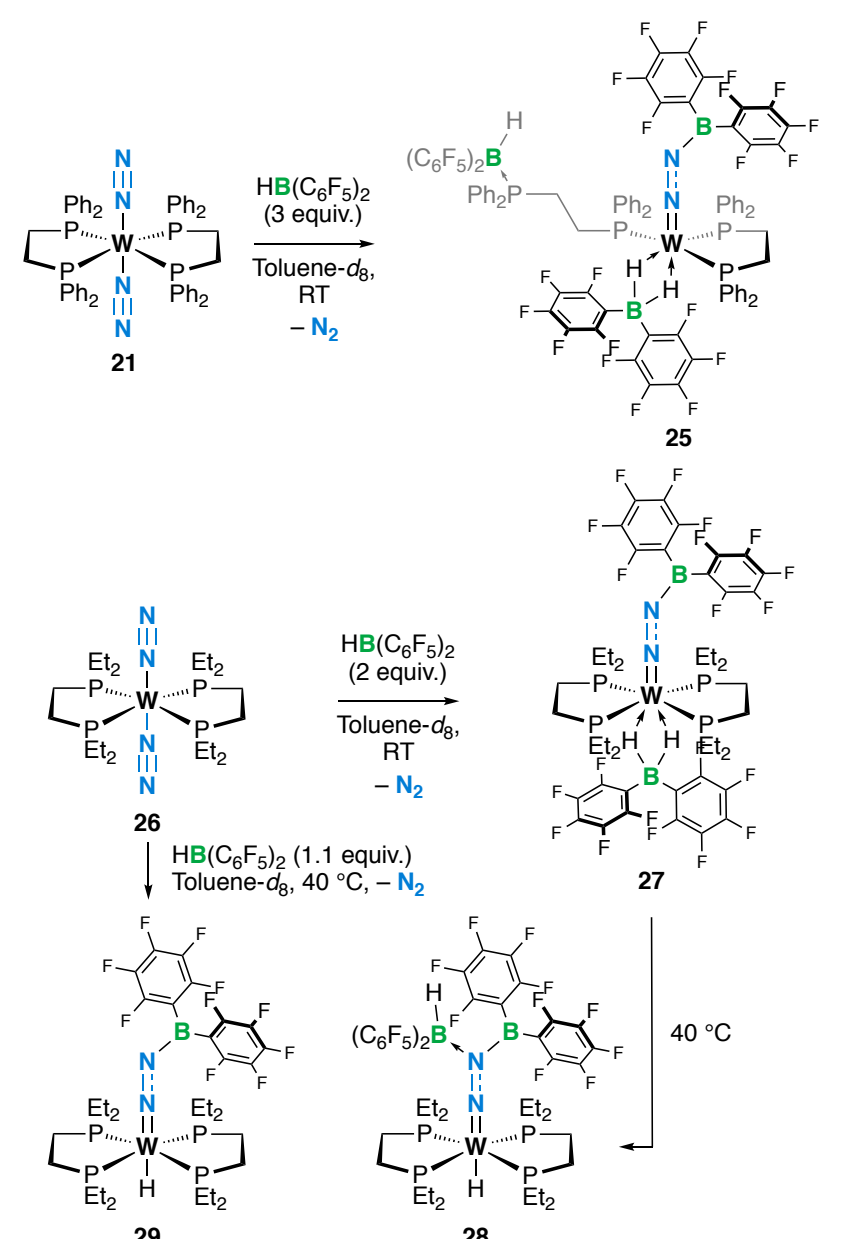

Scheme 6 From borylation of $\mathrm{N}_{2}$ to $1,3-\mathrm{B}-\mathrm{H}$ bond addition over a $\mathrm{M}-\mathrm{N}_{2}$ unit using Piers' borane

This last experiment suggested that in $\mathbf{2 8}$, one equivalent of $\mathrm{HB}\left(\mathrm{C}_{6} \mathrm{~F}_{5}\right)_{2}$ can dissociate to enter a new 1,3-B-H bond addition process. From this we proposed a catalytic effect for Piers' borane in the $\mathbf{2 6} \longrightarrow \mathbf{2 9}$ transformation, as visualised in Scheme 7. The boron reagent has three roles: i) borylation agent, ii) B$\mathrm{H}$ bond cleavage and $\mathrm{iii}$ ) shuttling the hydride to the metal.

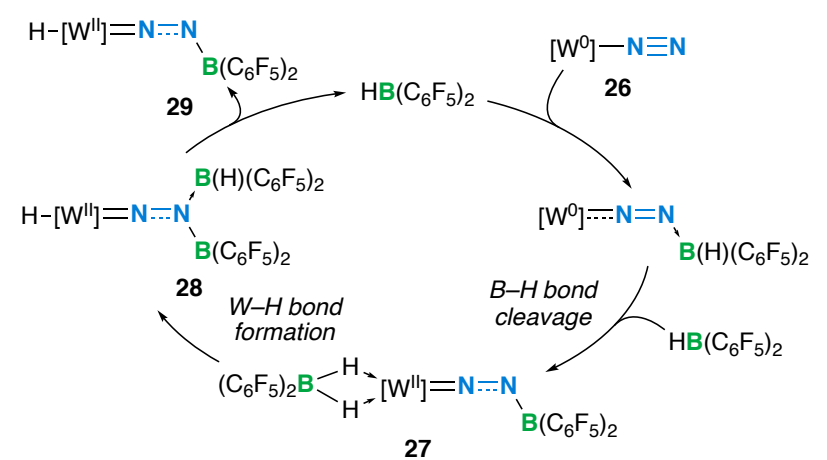

Scheme 7 A Piers' borane-driven catalytic cycle for 1,3-B-H bond addition

More recently, we have shown that Piers' borane can be employed as a catalyst to assist $1,3-\mathrm{B}-\mathrm{H}$ bond addition over the $\mathrm{W}-\mathrm{N} \equiv \mathrm{N}$ unit of $\mathbf{2 6}$ of otherwise unreactive boranes (Scheme 8). ${ }^{21}$ Thus, boryldiazenido compounds $\mathbf{3 0}$ and $\mathbf{3 1}$ have been obtained from treatment of 26 with $\mathrm{HBCy}_{2}$ or $\mathrm{HBIpc}_{2}$ (Cy = cyclohexyl, Ipc = isopinocampheyl) and catalytic amounts (10 mol\%) of Piers' borane. In these reactions, primary alkyl boranes, stemming from retro-hydroboration processes undergone by $\mathrm{HBCy}_{2}$ and $\mathrm{HBIPc}_{2}$, are the species reacting with the $\mathrm{N}_{2}$-complex. 9-BBN, which was stable towards retrohydroboration, reacted much more sluggishly under catalytic conditions (26 $\longrightarrow$ 32). From additional experiments, we have highlighted the possibility that $1,3-\mathrm{B}-\mathrm{H}$ bond addition of Piers' borane onto $\mathbf{2 6}$ to give $\mathbf{2 9}$, followed by boron to boron $\mathrm{H}^{-}$transfer in a $\sigma$-bond metathesis sequence lead to the formation of the observed boryldiazenido compounds. Surprisingly, catecholborane (HBcat) spontaneously added to the W complex without the need for a catalyst, leading to a dimeric boryldiazenido complex 33 . We have not been able to collect experimental evidence suggesting a similar mechanism than for Piers' borane 1,3-addition, but we believe that the high hydride donor ability of either $\mathrm{L} \bullet \mathrm{HBcat}$ or $\left[\mathrm{H}_{2} \mathrm{Bcat}\right]^{-}$as well as the formation of dimers offer a thermodynamic driving force to this process that counter-balance its weak Lewis acidity, whereas the low steric hindrance of HBcat imparts a kinetic advantage. 


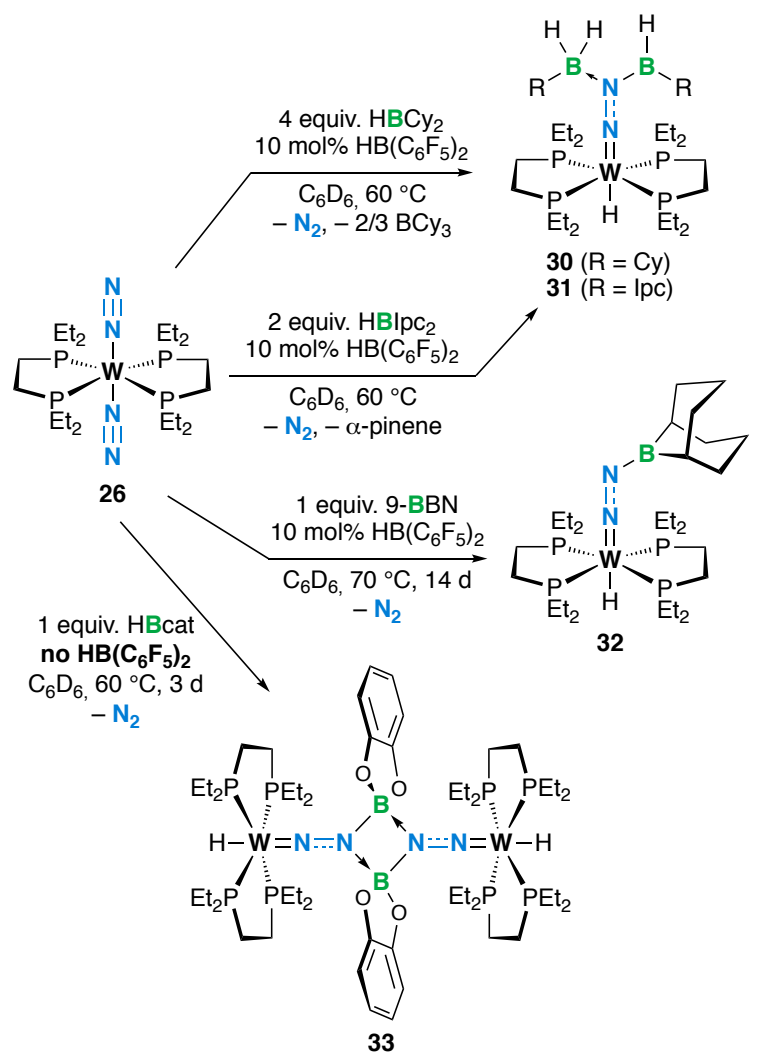

Scheme 8 Catalysed and uncatalysed 1,3-B-H bond addition with various hydroboranes.

\section{1,3 Haloboration}

The group of Braunschweig has recently shown that the $\mathrm{W}$ complex $\mathbf{2 1}$ is also reactive towards tri- and dihalo(aryl)boranes. ${ }^{22}$ The latter reacted with $\mathbf{2 1}$ through a formal 1,3-haloboration, allowing the preparation of boryldiazenido compounds $\mathbf{3 3}$ and Ar34-X (Scheme 9). Chloroboranes reacted more sluggishly than the bromo derivatives. The authors suggested that a comparable mechanism than the one we proposed for 1,3-B-H bond addition took place, the halide being shuttled to the metal centre by a second equivalent of borane. Further reactivity of the haloboryldiazenido complexes bearing mesityl and duryl substituents was explored. Bromide substitution at boron with various aryllithium reagents could be achieved (Mes34- $\mathrm{Br} \longrightarrow \mathbf{3 5}$ ), forcing in some instances an almost linear geometry for the W-N-N-BAr 2 motif. Reaction with $\mathrm{N}, \mathrm{N}$ dimethylaminopyridine (DMAP) resulted either in Lewis acidbase pairing (Mes34- $\mathrm{Br} \rightarrow 36$ ) or bromide substitution to give the borenium compound 37 . When treated with methyl triflate (MeOTf), the mesityl derivative underwent smooth $\mathrm{N}$-alkylation to provide the cationic borylmethylhydrazido complex $\mathbf{3 8}$.

\section{Borylamine synthesis from $\mathrm{N}_{2}$-derived Molybdenum nitrides}

The above described examples all implied the reactivity of a $\mathrm{N}_{2}$ unit with a boron reagent, but $\mathrm{N}_{2}$-derived nitrides issued from bimetallic $\mathrm{N}_{2}$ cleavage by low-valent metal centres are also species to look at for $\mathrm{N}_{2}$ transformation. While previous reports have shown their ability to react with carbon electrophiles to ultimately lead to the release of nitriles after several chemical steps, the development of catalytic $\mathrm{N}_{2}$ transformation relying on $\mathrm{N}_{2}$ cleavage is, like most other examples of nitrogen compound synthesis from $\mathrm{N}_{2}$ complexes, plagued by incompatibility issues between the functionalising reagent (generally an electrophile) and the strong reducing agent needed to access the low oxidation states to effect $\mathrm{N}_{2}$ activation. From this appraisal, the group of Mézailles has looked at $\mathrm{N}-\mathrm{Si}$ and $\mathrm{N}-\mathrm{B}$ bond formation between the $\mathrm{N}_{2}$-derived nitrido Mo-complex $\mathbf{4 0}$ supported by a triphosphine ligand and hydrosilanes ${ }^{23}$ or pinacolborane (HBpin) as mild electrophiles. In the latter case, HBpin was shown to add in a 1,2 fashion over the MoN unit, affording a borylimido complex $\mathbf{4 1}$ (Scheme 10). ${ }^{24}$ The authors have also shown that $\mathbf{4 1}$ can also be obtained when the $\mathrm{N}_{2}$ splitting step, employing the strong $\mathrm{Na}(\mathrm{Hg})$ reductant, was performed in the presence of HBpin (39 $\rightarrow$ 41).

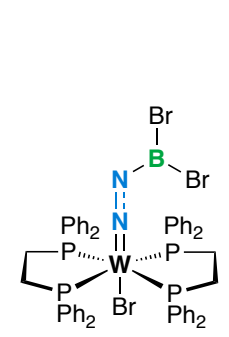

33

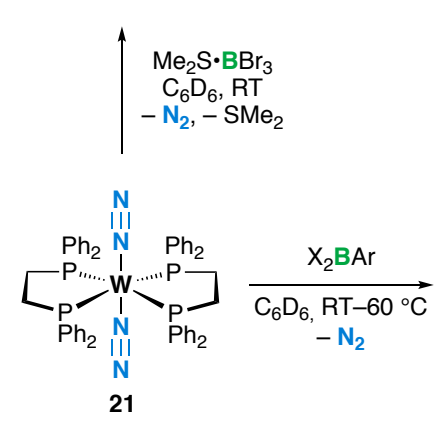

21

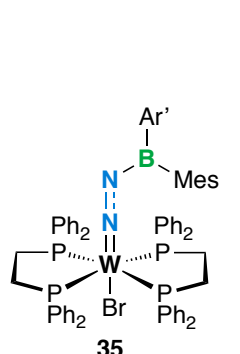

$\left(\mathrm{Ar}^{\prime}=\mathrm{Ph}\right.$, Dur or Mes)

$$
\begin{array}{c|c}
\mathrm{Ar}=\mathrm{Mes} & \mathrm{Ar} ' \mathrm{Li} \\
\mathrm{X}=\mathrm{Br} & -\mathrm{LiBr}
\end{array}
$$$$
\text { X = Br }
$$

Ar34-X

$\mathrm{Ar}=$ Mes, Dur or Fc $\mathrm{X}=\mathrm{Cl}$ or $\mathrm{Br}$

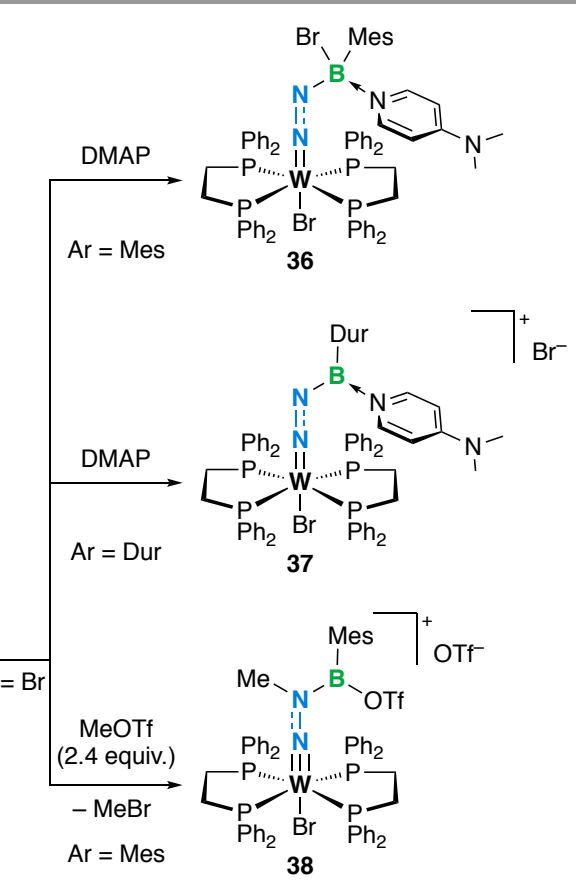


Remarkably, when $\mathbf{4 1}$ was treated with a 20-fold excess of borane, a mixture of primary to tertiary borylamines 42-44 and paramagnetic Mo complexes were obtained upon heating, the nitrogen compounds being collected in an almost quantitative yield with respect to $\mathbf{4 1}$, as measured by ammonium formation after acidic hydrolysis of the borylamines mixture. After abstraction of the iodide by $\mathrm{Tl}^{+}$to liberate a coordination site in the borylimido complex 41, the obtained cationic complex showed improved reactivity towards a second equivalent of
HBpin, affording the bis(boryl)amido dihydrido Mo complex 45 in $5 \mathrm{~min}$ at RT. After addition of a third equivalent, tris(boryl)amine $\mathbf{4 2}$ is obtained in $90 \%$ yield, along with small amounts of bis(boryl)amine $\mathbf{4 3}$ and the cationic Mo trihydride complex 46. Closure of a synthetic cycle from the latter back to $\mathbf{4 0}$ or $\mathbf{4 1}$ has not been unveiled yet; the achievement of such reaction would make a solid basis to next envision the development of a catalytic borylamine synthesis.

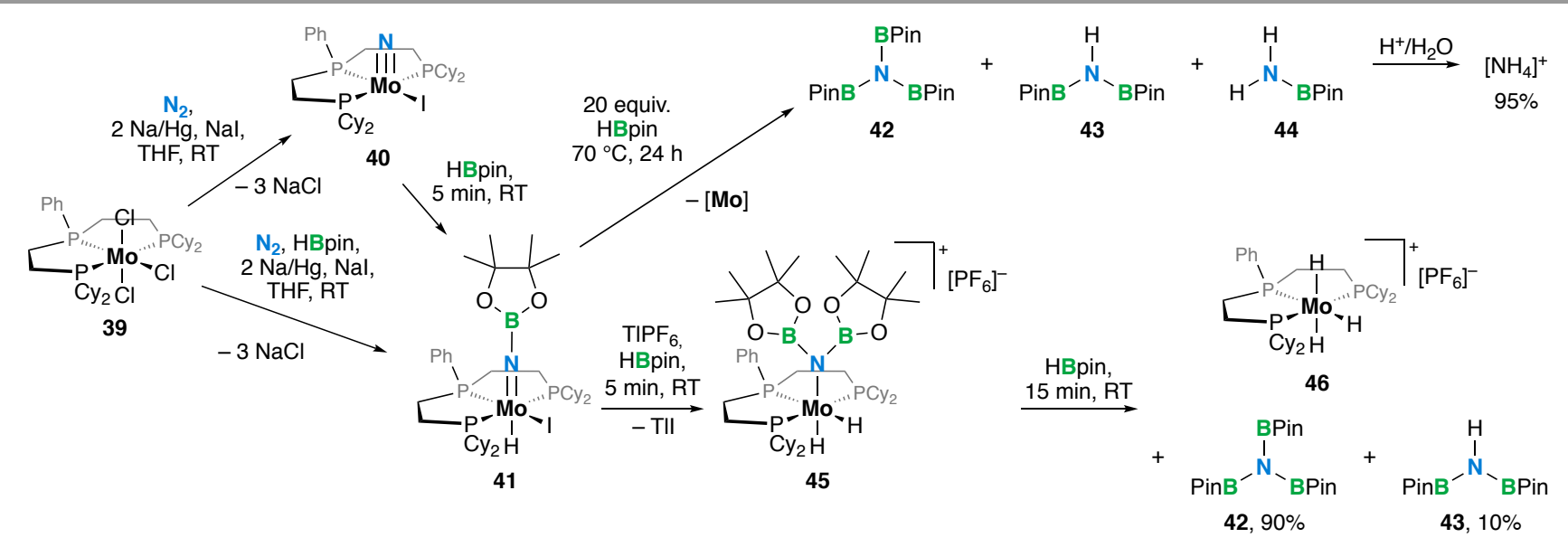

Scheme 10 Generation of Mo-nitrido and -borylimido complexes from $\mathrm{N}_{2}$ and production of borylamines from them.

\section{Conclusion}

Various B-N bond formation methods between transition metal-activated dinitrogen and boranes have been disclosed since chemists have started to explore the reactivity of coordinated dinitrogen or $\mathrm{N}_{2}$-derived nitrides. However, the examples gathered in this focus show that it is only recently that borane reactivity was systematically explored with dinitrogen complexes when compared to $\mathrm{N}-\mathrm{C}$ or $\mathrm{N}-\mathrm{Si}$ bond formation. This might be correlated with the growing interest over the last two decades for inorganic $\mathrm{B} / \mathrm{N}$ compounds and materials. In addition, the reader may have realized that examples of $\mathrm{N}_{2}$ borylation are missing with $\mathrm{N}_{2}$ complexes beyond group 6. Yet, to date, promising routes have been uncovered, where mildly electrophilic hydroboranes were shown to be sufficiently reactive to functionalise dinitrogen (or $\mathrm{N}_{2}$-derived nitrido complexes). While in most of the examples discussed above the release of a boron-nitrogen compound was not reported, the recent achievement of stoichiometric borylamine synthesis described in the last section paves the way for catalytic processes to emerge. In addition, it is worth noting that direct borylation of $\mathrm{N}_{2}$ using low-valent boron species was recently achieved by the group of Braunschweig. ${ }^{25}$ This presage other exciting developments for dinitrogen borylation.

\section{Conflicts of interest}

There are no conflicts to declare.

\section{Acknowledgements}

A. S. is indebted to the European Research Council for funding (grant agreement 757501).

\section{References}

1 (a) L. C. Seefeldt, Z.-Y. Yang, D. A. Lukoyanov, D. F. Harris, D. R. Dean, S. Raugei and B. M. Hoffman, Chem. Rev., 2020, 120, 5082-5106; (b) O. Einsle and D. C. Rees, Chem. Rev., 2020, 120, 4969-5004; (c) B. M. Hoffman, D. Lukoyanov, Z.-Y. Yang, D. R. Dean and L. C. Seefeldt, Chem. Rev., 2014, 114, 40414062.

2 (a) G. Ertl, Angew. Chem. Int. Ed., 2008, 47, 3524-3535; (b) J. W. Erisman, M. A. Sutton, J. Galloway, Z. Klimont and W. Winiwarter, Nat. Geosci., 2008, 1, 636; (c) R. Schlögl, Angew. Chem. Int. Ed., 2003, 42, 2004-2008; (d) V. Smil, Enriching the Earth: Fritz Haber, Carl Bosch, and the Transformation of World Food Production, Mit Press, 2001; (e) J. R. Jennings, Catalytic Ammonia Synthesis: Fundamentals and Practice, Springer, 1991; (f) F. Haber, The Synthesis of Ammonia from Its

Elements, https://www.nobelprize.org/prizes/chemistry/1918/haber/le cture/, (accessed 8 March 2021).

3 (a) F. Masero, M. A. Perrin, S. Dey and V. Mougel, Chem. Eur. J., 2021, 27, 3892-3928; (b) S. Kim, F. Loose and P. J. Chirik, Chem. Rev., 2020, 120, 5637-5681; (c) D. Singh, W. R. Buratto, J. F. Torres and L. J. Murray, Chem. Rev., 2020, 120, 55175581; (d) Y. Nishibayashi, Ed., Transition Metal-Dinitrogen Complexes: Preparation and Reactivity, Wiley-VCH Verlag $\mathrm{GmbH}$ \& Co. KGaA, Weinheim, Germany, 2019; (e) R. J. Burford and M. D. Fryzuk, Nat. Rev. Chem., 2017, 1, 26; (f) Y. Nishibayashi, Ed., Nitrogen Fixation, Springer International Publishing AG, Cham, Switzerland, 2017; (g) M. D. Walter, in Advances in Organometallic Chemistry, ed. P. J. Pérez, Academic Press, 2016, vol. 65, pp. 261-377.

4 (a) M. J. Chalkley, M. W. Drover and J. C. Peters, Chem. Rev., 2020, 120, 5582-5636; (b) N. Stucke, B. M. Flöser, T. Weyrich and F. Tuczek, Eur. J. Inorg. Chem., 2018, 2018, 1337-1355; (c) Y. Nishibayashi, Dalton Trans., 2018, 47, 11290-11297; (d) S. L. Foster, S. I. P. Bakovic, R. D. Duda, S. Maheshwari, R. D. Milton, S. D. Minteer, M. J. Janik, J. N. Renner and L. F. 
Greenlee, Nat. Catal., 2018, 1, 490-500; (e) Y. Roux, C. Duboc and M. Gennari, ChemPhysChem, 2017, 18, 2606-2617.

5 (a) S. Bernard, C. Salameh and P. Miele, Dalton Trans., 2016 , 45, 861-873; (b) P. Miele and S. Bernard, Macromol. Contain. Met. Met. Elem., 2007, 103-120; (c) D. Cornu, S. Bernard, S. Duperrier, B. Toury and P. Miele, J. Eur. Ceram. Soc., 2005, 25, 111-121.

6 T. Shima, S. Hu, G. Luo, X. Kang, Y. Luo and Z. Hou, Science, 2013, 340, 1549-1552.

7 Riken Corp., Japan ., PCT Int. Appl., 2014, 54pp.

8 Z. Mo, T. Shima and Z. Hou, Angew. Chem. Int. Ed., 2020, 59 8635-8644.

9 B. Wang, G. Luo, M. Nishiura, S. Hu, T. Shima, Y. Luo and Z. Hou, J. Am. Chem. Soc., 2017, 139, 1818-1821.

10 S. Mellino, L. C. Stevenson, E. Clot and P. Mountford, Organometallics, 2017, 36, 3329-3342.

11 (a) J. A. Pool, E. Lobkovsky and P. J. Chirik, Nature, 2004, 427 527-530; (b) W. H. Bernskoetter, E. Lobkovsky and P. J. Chirik, J. Am. Chem. Soc., 2005, 127, 14051-14061; (c) W. H. Bernskoetter, J. A. Pool, E. Lobkovsky and P. J. Chirik, J. Am. Chem. Soc., 2005, 127, 7901-7911; (d) W. H. Bernskoetter, A. V Olmos, E. Lobkovsky and P. J. Chirik, Organometallics, 2006, 25, 1021-1027; (e) P. J. Chirik, Dalton Trans., 2007, 16-25; (f) W. H. Bernskoetter, E. Lohkovsky and P. J. Chirik, Angew. Chem. Int. Ed., 2007, 46, 2858-2861; (g) D. Pun, C. A. Bradley, E. Lobkovsky, I. Keresztes and P. J. Chirik, J. Am. Chem. Soc. 2008, 130, 14046-14047; (h) D. J. Knobloch, H. E. Toomey and P. J. Chirik, J. Am. Chem. Soc., 2008, 130, 4248-4249; (i) D. Benito-Garagorri, W. H. Bernskoetter, E. Lobkovsky and P. J. Chirik, Organometallics, 2009, 28, 4807-4813; (j) D. J. Knobloch, E. Lobkovsky and P. J. Chirik, J. Am. Chem. Soc. 2010, 132, 10553-10564; (k) D. J. Knobloch, E. Lobkovsky and P. J. Chirik, J. Am. Chem. Soc., 2010, 132, 15340-15350; (I) D. J. Knobloch, E. Lobkovsky and P. J. Chirik, Nat. Chem., 2010, 2, 30-35; (m) S. P. Semproni, E. Lobkovsky and P. J. Chirik, J. Am. Chem. Soc., 2011, 133, 10406-10409; (n) D. J. Knobloch, S. P. Semproni, E. Lobkovsky and P. J. Chirik, J. Am. Chem. Soc., 2012, 134, 3377-3386; (o) S. P. Semproni, G. W. Margulieux and P. J. Chirik, Organometallics, 2012, 31, 6278-6287; (p) S. P. Semproni and P. J. Chirik, Eur. J. Inorg. Chem., 2013, 2013, 3907-3915; (q) S. P. Semproni and P. J. Chirik, J. Am. Chem Soc., 2013, 135, 11373-11383; (r) G. W. Margulieux, S. P. Semproni and P. J. Chirik, Angew. Chem. Int. Ed., 2014, 53 9189-9192; (s) S. P. Semproni and P. J. Chirik, Organometallics, 2014, 33, 3727-3737.

12 M. D. Fryzuk, Acc. Chem. Res., 2008, 42, 127-133.

13 (a) M. D. Fryzuk, B. A. MacKay, S. A. Johnson and B. O. Patrick, Angew. Chem. Int. Ed., 2002, 41, 3709-3712; (b) B. A. MacKay, S. A. Johnson, B. O. Patrick and M. D. Fryzuk, Can. J. Chem., 2005, 83, 315-323.

14 F. Studt, B. A. MacKay, S. A. Johnson, B. O. Patrick, M. D. Fryzuk and F. Tuczek, Chem. Eur. J., 2005, 11, 604-618.

15 H. Ishino, Y. Ishii and M. Hidai, Chem. Lett., 1998, 27, 677-678.

16 (a) J. C. Slootweg and A. Jupp, Eds., in Molecular Catalysis 2, Springer International Publishing, 2021; (b) G. Erker and D. W. Stephan, Eds., in Topics in Current Chemistry 332, SpringerVerlag Berlin Heidelberg, 2013; (c) G. Erker and D. W. Stephan, Eds., in Topics in Current Chemistry 334, Springer-Verlag Berlin Heidelberg, 2013.

17 E. A. Patrick and W. E. Piers, Chem. Commun., 2020, 56, 841853 .

18 M. A. Dureen, A. Lough, T. M. Gilbert and D. W. Stephan, Chem. Commun., 2008, 4303-4305.

19 A. Simonneau, R. Turrel, L. Vendier and M. Etienne, Angew. Chem. Int. Ed., 2017, 56, 12268-12272.

20 A. Coffinet, D. Specklin, L. Vendier, M. Etienne and A. Simonneau, Chem. Eur. J., 2019, 25, 14300-14303.

21 A. Coffinet, D. Zhang, L. Vendier, S. Bontemps and A. Simonneau, Dalton Trans., 2021, 50, DOI: 10.1039/D1DT00317H
22 A. Rempel, S. K. Mellerup, F. Fantuzzi, A. Herzog, A Deißenberger, R. Bertermann, B. Engels and H. Braunschweig, Chem. Eur. J., 2020, 26, 16019-16027.

23 (a) Q. Liao, A. Cavaillé, N. Saffon-Merceron and N. Mézailles, Angew. Chem. Int. Ed., 2016, 55, 11212-11216; (b) S. Bennaamane, M. F. Espada, I. Yagoub, N. Saffon-Merceron, N. Nebra, M. Fustier-Boutignon, E. Clot and N. Mézailles, Eur. J. Inorg. Chem., 2020, 2020, 1499-1505.

24 M. F. Espada, S. Bennaamane, Q. Liao, N. Saffon-Merceron, S. Massou, E. Clot, N. Nebra, M. Fustier-Boutignon and N. Mézailles, Angew. Chem. Int. Ed., 2018, 57, 12865-12868.

25 (a) M.-A. Légaré, G. Bélanger-Chabot, R. D. Dewhurst, E. Welz, I. Krummenacher, B. Engels and $\mathrm{H}$. Braunschweig, Science, 2018, 359, 896-900; (b) M.-A. Légaré, M. Rang, G. BélangerChabot, J. I. Schweizer, I. Krummenacher, R. Bertermann, M. Arrowsmith, M. C. Holthausen and H. Braunschweig, Science, 2019, 363, 1329-133; (c) M.-A. Légaré, G. Bélanger-Chabot, M. Rang, R. D. Dewhurst, I. Krummenacher, R. Bertermann and H. Braunschweig, Nat. Chem., 2020, 12, 1076-1080. 